\title{
E-recruitment: new practices, new issues. An exploratory study
}

\author{
(draft) \\ Girard Aurélie ${ }^{1}$, Bernard Fallery ${ }^{1}$ \\ ${ }^{1}$ CREGOR, Case Courrier 028, University of Montpellier 2, 34000 Montpellier, France \\ Aurelie.girard340orange.fr \\ Bernard.falleryduniv-montp2. fr \\ http://www.cregor.net
}

\begin{abstract}
The Internet as already impacts the recruitment process and the development of Web 2.0 offers recruiters new perspectives. Are web 2.0 practices revealing new e-recruitment strategies? We connect first the RBV and the SNT respectively with Web 1.0 and Web 2.0. Then, we present the results from an exploratory study conducted among recruiters in software and computing services companies. It appears that the use of Web 1.0 is generalized but that it is becoming insufficient. Web 2.0 is used by firms to develop employer branding and a reputation and to create new relationships with potential applicants.
\end{abstract}

\section{Introduction}

"Every sector, every job, every function, was, is or will be disrupted by Internet" stated Kalika in 2000 [19]. The HR sector is undergoing a transformation. In August 2007, Monster France had more than 3 million CVs on their databases and LinkedIn's social network had over 36 million members around the world in February 2009.

According to Lepak and Snell (1998) [22], the HR Function must confront four seemingly contradictory pressures. HR departments are required to be simultaneously strategic, flexible, efficient, and customer-oriented. Certain authors have suggested that the use of technology may enable them to achieve these goals [36, 22, 21]. Recruitment plays a critical role in enhancing organizational survival and success [29]. The recruitment process has been profoundly affected by major changes: the retirement of the "baby boomers", an increasing need for flexibility and responsiveness, and complex modes of communication. The development of new "social and sociable" media technology [26] called "Web 2.0" offers companies and their recruiters new perspectives. Despite the growing importance of e-recruitment, research in this area remains very limited and applicant-oriented [6, 23].

Our main research issue is: Are web 2.0 practices revealing new e-recruitement strategies?

In the first part of this paper we linked the Resource Based View with Web 1.0 and the Social Network Theory with Web 2.0. In the second part, the results of an exploratory study on the recruitment practices of Software and Computing Services Companies (SCSC) are exposed. Both parts, give us the possibility to develop an e-recruitment model based on Ruël et al.'s (2004) [36] e-HRM model. 2. 


\section{Competencies, social networks and e-recruitment}

\subsection{Resource-Based View and e-recruitment 1.0}

The recruitment process is in harmony with a comprehensive approach to competence management [11]: acquire, promote and regulate individual and collective skills. Today, competence management is considered to be strategic and a source of competitive advantage [12].

Thus, according to the Resource-Based View [2], companies should not be seen only in terms of their business portfolio, but should be defined as a unique set of tangible and intangible resources, a portfolio of core competencies and distinct resources [33]. Employees also play a real role in the success of organizations.

The nature of work in the 21 st century presents many challenges for recruitment [32]: knowledge-based work places greater demands on employee competencies; demographic, societal, and cultural changes are widespread and are creating an increasing global shortfall in the number of qualified applicants; the workforce is also increasingly diverse [32]. Chambers et al. [8] use the term "the war for talents".

Recruitment is thus the first stage in a comprehensive approach to competence and talent management. Peretti (2004) [31] divides the recruitment activity into four stages: preparation, research, selection and integration. With the Internet, recruitment methods are evolving and diversifying. According to a recent survey conducted by APEC [1], the French association for executive employment, the job market is becoming more and more transparent: $63 \%$ of recruitment operations result in job advertisements. E-recruitment can be defined as "the use of any technology to attract, select or manage the recruitment process" [30] (p. 5).

In this perspective we can distinguish three main aspects of web 1.0:

Career websites to improve the visitor's knowledge of a company, promote an attractive image of an employer and of course generating applications [9, 27].

Job boards to give companies the possibility of communicating their job offers to a large public. Job boards can be generalist, like Monster, or specialized to provide more targeted information and more qualified CVs [13].

Recruitment systems have several benefits: cost reduction, efficiency gains, improved service to clients and improved strategic orientation [30]. Lee (2005) [20] developed a five-stage evolution model for the e-recruiting system.

The development of these different tools gives companies the possibility to access to important data bases of competencies. With Web 1.0 applications they can communicate on a large scale, target and manage the future core competencies of the company to obtain a competitive advantage in line with the RBV.

\subsection{Social Network Theory and e-recruitment 2.0}

Social Network and Social Capital are two closely linked notions that can be assessed in terms of three dimensions: the strength of the ties, the network's structure and the nature of the contact attributes.

Bourdieu (1986) [5] defined social capital as "the aggregate of actual or potential resources which are linked to possession of a durable network of more or less institutionalized relationships of more or mutual acquaintance and recognition" ( $\mathrm{p}$. 248). Granovetter (1973) [16] has regularly used the job market to illustrate "the strength of weak ties". Burt (1992) [7] qualify the absence of bridges between groups as "structural holes" and highlights the competitive advantage it represents with 
respect to informational benefits. Coleman (1988) [10] and Putnam (1995) [34] do not share this point of view. They highlight the importance of trust in the development of social capital. For Lin et al. (1981) [24], what is important it is not the strength of the ties maintained with an individual, but the resources accessible through the latter: the higher the contact status used, the higher the occupational status obtained.

From an applicant's point of view, mobilizing a social network makes it possible to obtain more information about the company and the job $[35,16,18]$. This method may also enable applicants to acquire better wages [17, 18]). From an employer's perspective, according to Rees (1966) [35], making use of one's own network or that of the staff should limit the number of applications whilst simultaneously ensuring their quality and also reduce absenteeism and turnover. This method is both less expensive and more effective because of the confidence there is in the applications [18]. Companies no longer think twice about seeking out their employees' networks. Some have formalized this method and put in place an effective cooptation policy. A survey conducted by DARES shows that over $50 \%$ of recruiters mobilize their networks during the recruitment process [15].

Social network has been widely associated with the term Web 2.0 [28]. This term is still much criticized; however, it represents real evolution in the Web. Web 1.0 fitted into a scheme of "author to readers" while the Web 2.0 tends to reduce hierarchies by allowing readers to become real actors. It is user-centered and it enhances information sharing.

In the recruitment framework, the most representative Web 2.0 tools are:

Blogs, created by applicants and employers and headhunters (Hightech-job).

Online Social Networks: Facebook or professional (LinkedIn or Viadeo) to find customers, partners and future employees, to hunt and contact "passive" applicants.

Virtual worlds: In June 2007, the first French recruitment forum on Second Life, was organized (1,500 participants).

Cooptation websites where people are motivated (financially speaking) to find potential applicants within their entourage and to attract to new talents (Jobmeeters).

Identity management websites, such as Ziki, improve the visibility on the internet by, for example, centralizing and synchronizing on one page: your blog, your social profiles... and by promoting your page through a Google commercial link.

RSS feeds (Real Simple Syndication), where updated information can be automatically posted on a search engine of job offers (Moovement for example), or RSS aggregators (like Netvibes and iGoogle).

Video platforms, such as Youtube or Youjob, give companies the opportunity to present their job offers, and applicants the possibility of introducing their CV.

Web 2.0 gives companies the possibility to put forward and increase their social capital. Employees and applicants can have access to a wider network, maintain and develop new relationships. Recruiters can directly contact people with interesting profiles which did not apply before. According to the SNT, developing, mobilizing a social network represents several advantages for both applicants and employers.

\section{Results of an exploratory study}

The aim of this study is to determine if Web 2.0 tools are really used by companies, how they use it and for what purpose. In the present case, we have chosen to study software and computing service companies (SCSC). They have considerable recruitment activity and they use Internet widely. 
The exploratory study was carried out from May to June 2008. It was based on semi-directive interviews, with either face to face or telephone interviews. This method of data collection is justified by the exploratory nature of the study and the type of data collected: current recruitment practices, the practices that are considered, reasons, opinions. The sample was chosen for convenience. Although the size of the sample may seem small, if we consider the size of the companies interviewed and their recruitment dynamism, this sample nevertheless provides a global view of the phenomenon. Data saturation was achieved after eleven interviews; those interviews have been recorded and transcribed.

Table 1. Sample characteristics

\begin{tabular}{|l|l|}
\hline $\begin{array}{l}\text { Number of people } \\
\text { number of companies }\end{array}$ & $\begin{array}{l}11 \text { recruiters including } 2 \text { from the same company (1 located in a } \\
\text { country city and the other in the Head Office). }\end{array}$ \\
\hline $\begin{array}{l}\text { Affiliated organization } \\
\text { size }\end{array}$ & $\begin{array}{l}1 \text { company has less than } 100 \text { employees, } 3 \text { between } 2,500 \text { and } \\
4,999,4 \text { between } 5,000 \text { and } 10,000,2 \text { more than } 10,000 .\end{array}$ \\
\hline $\begin{array}{l}\text { Location and local } \\
\text { agency size }\end{array}$ & $\begin{array}{l}5 \text { people were at the Head Office, } 6 \text { at local agencies: 1 agency } \\
\text { has less than } 100 \text { employees, } 5 \text { between } 100 \text { and } 500 .\end{array}$ \\
\hline $\begin{array}{l}\text { Recruitment plan for } \\
\mathbf{2 0 0 8}\end{array}$ & $\begin{array}{l}1 \text { company does not have specific objectives, } 2 \text { are planning } \\
\text { between } 500 \text { and } 1,000 \text { recruitments, } 7 \text { between } 1,500 \text { and } 2,500 .\end{array}$ \\
\hline
\end{tabular}

After transcription, a content analysis was performed by coding themes and defining a reading grid. A second phase of coding consisted in comparing each interview, from which five main results emerged. Pragmatic validity was estimated by sending results to participants and analyzing their comments.

\subsection{The competence profile is becoming more important than position profile.}

5 companies declared to think exclusively in terms of competence profile and not in terms of position profile. The 5 others adopt both types of recruitment, but think more in terms of competence. Each company mentioned that this practice enables them to anticipate their needs. Internships are a starting point for young graduates to integrate the organization. Applicants are mainly hired on an open-ended work contract. These results are in line with the strategic evolution of competence management [12].

\subsection{Web 1.0 is essential for recruitment transactions but is becoming insufficient}

Job boards, career websites and recruitment systems are used by all companies (see table 2). Most recruiters think that Web 1.0 enabled them to advertise job offers easily and cheaply, whilst appealing to a larger public and making better application management possible. This result is in line with Parry and Tyson (2008) [30].

However, considering the highly competitive environment in which SCSC operate, the classic Web (or Web 1.0) is becoming insufficient for recruitment purposes.

"The classic Web still remains a support that cannot be ignored [...] but it is not sufficient anymore". "Service companies have approximately the same needs and tend to contact the same profiles available on classic job boards, which tend to increase wage demands, expectations, and applicants'demands in general."

Table 2. Classic tools (Web 1.0) used by SCSC for recruiting.

\begin{tabular}{|l|l|l|l|l|l|l|l|l|l|l|}
\hline Means & 1 & 2 & 3 & 4 & 5 & 6 & 7 & 8 & 9 & 10 \\
\hline Job boards & $\mathrm{x}$ & $\mathrm{x}$ & $\mathrm{x}$ & $\mathrm{x}$ & $\mathrm{x}$ & $\mathrm{x}$ & $\mathrm{x}$ & $\mathrm{x}$ & $\mathrm{x}$ & $\mathrm{x}$ \\
\hline
\end{tabular}




\begin{tabular}{|l|l|l|l|l|l|l|l|l|l|l|}
\hline Career websites & $\mathrm{X}$ & $\mathrm{X}$ & $\mathrm{X}$ & $\mathrm{X}$ & $\mathrm{X}$ & $\mathrm{X}$ & $\mathrm{X}$ & $\mathrm{X}$ & $\mathrm{X}$ & $\mathrm{X}$ \\
\hline Software & $\mathrm{X}$ & $\mathrm{X}$ & $\mathrm{X}$ & $\mathrm{X}$ & $\mathrm{X}$ & $\mathrm{X}$ & $\mathrm{X}$ & $\mathrm{X}$ & $\mathrm{X}$ & $\mathrm{X}$ \\
\hline Internships & $\mathrm{X}$ & $\mathrm{X}$ & $\mathrm{X}$ & $\mathrm{X}$ & $\mathrm{X}$ & $\mathrm{X}$ & $\mathrm{X}$ & $\mathrm{X}$ & $\mathrm{X}$ & $\mathrm{X}$ \\
\hline Cooptation policy & $\mathrm{X}$ & $\mathrm{X}$ & & $\mathrm{X}$ & $\mathrm{X}$ & $\mathrm{X}$ & & $\mathrm{X}$ & $\mathrm{X}$ & \\
\hline Recruitment agencies & $\mathrm{X}$ & $\mathrm{X}$ & & $\mathrm{X}$ & & & $\mathrm{X}$ & $\mathrm{X}$ & & $\mathrm{X}$ \\
\hline Events planning & $\mathrm{X}$ & $\mathrm{X}$ & $\mathrm{X}$ & $\mathrm{X}$ & $\mathrm{X}$ & $\mathrm{X}$ & $\mathrm{X}$ & $\mathrm{X}$ & $\mathrm{X}$ & \\
\hline
\end{tabular}

\subsection{Web 2.0 is used to develop an employer's branding and reputation}

SCSC use Web 2.0 as a complement to "real" events (student events, speed-recruiting sessions...). Web 2.0 is considered to be a means of communication and differentiation. SecondLife is the most representative example. Of the 10 companies contacted, 3 have already launched a recruitment session on Second Life in 2007. Few applicants were hired (about 1 to 3 recruitments) but it allowed the companies involved to convey an innovative image of themselves. However, no further recruitment sessions are planned. The others companies do not intend to invest in SecondLife. This is no longer considered to be as interesting as it used to be.

Table 3. Web 2.0 tools used by SCSC for recruiting.

\begin{tabular}{|c|c|c|c|c|c|c|c|c|}
\hline Web 2.0 & $\mathrm{x}$ & $\mathrm{x}$ & $\mathrm{x}$ & $\mathrm{x}$ & $\mathrm{X}$ & $\mathrm{x}$ & $\mathrm{x}$ & $\mathrm{x}$ \\
\hline SecondLife & $\mathrm{x}$ & & & $\mathrm{X}$ & & & & $\mathrm{X}$ \\
\hline Viadeo & $\mathrm{x}$ & $\mathrm{x}$ & & $\mathrm{x}$ & $\mathrm{x}$ & $\mathrm{x}$ & $\mathrm{x}$ & $\mathrm{x}$ \\
\hline Facebook & & & & & & & & $\mathrm{x}$ \\
\hline Video & $\mathrm{X}$ & $\mathrm{X}$ & $\mathrm{X}$ & & & $\mathrm{x}$ & & $\mathrm{x}$ \\
\hline Blogs & & & & & & $\mathrm{x}$ & & \\
\hline
\end{tabular}

\subsection{Web 2.0 makes it possible to manage new relationships with applicants}

Web 2.0 gives SCSC the opportunity to increase their social capital by creating new relationships and reaching out to potential applicants. Members of social networks are not always in-between jobs but they stay open to job opportunities. These "passive applicants" are interesting for SCSC that are constantly searching for new profiles.

"This technology [Web 2.0] makes it possible for us to approach applicants differently, nowadays we recruit differently".

Innovative practices appear and tend to develop. 7 companies use Viadeo's social network (since 2008). Facebook is used by one company through an application that allows employees to display open positions on their profiles. Another company is developing its own application. 5 companies have participated in recruitment sessions through video conferences via YouJob or Waliitech and/or have used video to hold an interview and promote the company (for example Enlignepourlemploi). One company has created blogs about different parts of its activities to demonstrate its expertise, develop communities, and promote the company. It uses the Netvibes aggregator to create a unique information space. These practices are recent; we do not have the required distance regarding the outcomes of Web 2.0.

Web 2.0 used as complementary information about an applicant that has already been identified has divided opinions. Three recruiters think that this practice enables them to see the applicant from a different perspective. The others were more critical, for several reasons, including lack of time, lack of efficiency and lack of ethics. 


\subsection{Two possible evolutions: decentralization of recruitment responsibilities or}

development of outsourcing

Of the 9 companies with local agencies, 8 have decentralized recruitment management. Each agency carries out its own research and interviews and has access to $\mathrm{CV}$ databases. The software makes it possible to share information better and encourages decentralization of recruitment responsibilities into the regions.

In addition, the development of online social networks could generate a decentralization of recruitment responsibilities to employees. 9 out of 10 companies have implemented a genuine cooptation policy. Companies declare that applications are generally of better quality. Web 2.0 could facilitate this policy. 2 companies encourage their teams to co-opt through these networks and develop their social capital. This decentralization phenomenon is in line with Ruël et al. (2004) [36].

Conversely, Web 2.0 practices could be externalized toward recruitment agencies. This possibility runs counter to the externalization conditions defined by Lepak and Snell (1998) [22], according to which the core HR activities are capable of being supported internally as a means of achieving competitive advantage. Recruitment agencies can, however, provide expertise and offer confidentiality.

Evolutions observed in the literature and in the exploratory study are presented in the table below. Obviously, e-Recruitment 1.0 and e-Recruitment 2.0 are not in opposition to one another; they may even be complementary.

Table 4. e-Recruitment 1.0 versus e-Recruitment 2.0

\begin{tabular}{|l|l|}
\hline e-Recruitment 1.0 & e-Recruitment 2.0 \\
\hline Large job boards & Development of new services, social networks \\
\hline Subscription to CV databases & Almost free CV and profiles (especially on blogs) \\
\hline E-mail alerts ("push mail" service) & RSS feeds, real-time information \\
\hline Basic job advertisement (text) & Rich media advertisement (audio, video, animation) \\
\hline $\begin{array}{l}\text { Active recruiters (job advertising) or } \\
\text { even passive recruiters (CV selection) }\end{array}$ & Proactive recruiters (social networks, blogs...) \\
\hline $\begin{array}{l}\text { Active applicants (CV posting, reply to } \\
\text { advertisement ) }\end{array}$ & $\begin{array}{l}\text { "Passive" or "Proactive" applicants (open to market } \\
\text { opportunities) }\end{array}$ \\
\hline Jobs forum & Virtual jobs forum, online events \\
\hline Classic communication (advertisment) & Development of employer's reputation and branding \\
\hline $\begin{array}{l}\text { Centralization } \\
\text { management }\end{array}$ & $\begin{array}{l}\text { Decentralization of recruitment responsibilities (easy } \\
\text { cooptation through social networks) and/or } \\
\text { Externalization toward recruitment agencies. }\end{array}$ \\
\hline $\begin{array}{l}\text { From Transactional recruitment (one- } \\
\text { shot, short term)... }\end{array}$ & $\begin{array}{l}\ldots \text { to Relational recruitment (applicant relationship } \\
\text { management, long term) or even transformational } \\
\text { recruitment (strategic role) }\end{array}$ \\
\hline
\end{tabular}

The literature review and exploratory study give a better understanding of recruitment issues. Internet is essential; the interviewed recruiters do not imagine recruitment without Internet. Web 1.0 brought tools giving access to important data bases of competencies. Web 2.0 reveals the shift from exchange-based recruitment practices to relationship-based approaches. Recruiters can increase their social capital by creating new relationships and reaching out to potential applicants. They can also develop employer branding and reputation and play a more strategic role within the company. 


\section{Discussion and conclusion}

Based on the literature review and exploratory study we can extend our research by developing an e-recruitment model adapted from Ruel et al.'s e-HRM model, following the same division: strategy, goals, type and outcomes (see Fig. 1).

Fig. 1. E-Recruitment model, adapted from Ruël et al.'s (2004) [36] e-HRM Model.

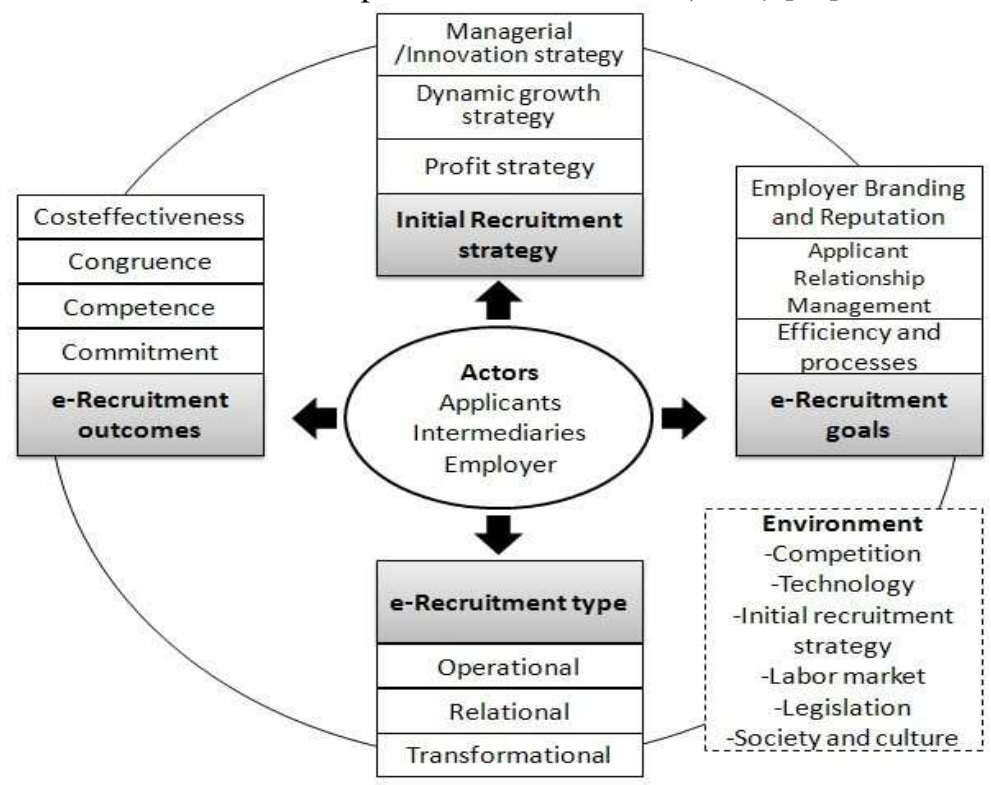

Initial recruitment strategy, in line with Beyssere des Horts (1987) [4]. Profit strategy is used in organizations with mature activities. The recruitment process is very standardized. Positions are explicitly described. We can refer to this as recruitment by profile. Dynamic growth strategy is used in organizations where activities are growing quickly. The recruitment process is not formalized and concerns applicants with high potential. It is recruitment by competence, favoring experienced profiles. Managerial strategy is used in organizations which are starting their activity or developing new ones. The recruitment process is open. It concerns mainly young applicants with potential. It is recruitment by competence, favoring young potential.

e-Recruitment goals. Efficiency and processes: the recruitment function, like the HR function, should work efficiently and be aware of costs [22, 21, 36]. Applicant relationship management: technology could make it possible to ensure better management of applications [30]. According to our exploratory study, Web 2.0 offers 
means for engaging relationships with passive applicants. Employer branding and reputation: HR practices can contribute to corporate reputations and branding [25], Web 2.0 can be a solid support.

e-Recruitment type, based on Lepak and Snell's (1998) [22] HRM type. Operational e-Recruitment: concerns basic e-Recruitment transactions characterized by short term applicant relationships, global messages and automation. Relational eRecruitment characterized by the development of "real" applicant relationships through better feed-back, and the use of Web 2.0 tools. Transformational eRecruitment concerns strategic e-Recruitment, anchored in a talent management strategy [14]. Employer branding and reputation could be a solid support.

e-Recruitment outcomes, adapted from Beer et al.'s (1984) [3] outcomes. High commitment: such outcomes can be characterized in terms of job satisfaction, psychological contract, motivation, integration. High competence: this points towards the ability employees have to learn new tasks and roles. It requires careful selection of employees from the beginning. Cost effectiveness can be attained by means of recruitment activities by accurately setting pay levels, rigorous selection that improves job satisfaction and performance. Higher congruence concerns the internal organization, the 'input, throughput, and output' of personnel structured in the interests of all stakeholders. Recruitment represents an 'input' of personnel, which is the basis for developing a coherent and satisfying workforce organization.

As a conclusion, new practices and issues are emerging. Nowadays, Internet seems essential for recruitment activity. Web 1.0 brought tools giving access to important data bases of competencies. Web 2.0 reveals the shift from exchange-based recruitment practices to relationship-based approaches.

The model makes it possible to obtain a global view of e-recruitment issues. It must now be validated by means of empirical research. Other sectors and other type of recruiters (for example headhunters) are worth considering in order to see the possible differences in e-recruitment practices. It would be interesting to adopt a dual approach, by studying the applicant's point of view to detect what changes Web 2.0 brings to their professional development. European comparison would make it possible to identify the differences in practices. It could be worth considering other issues especially reputation, privacy and security issues.

\section{References}

1. APEC (2006). Le marché de l'emploi cadre à l'heure d'Internet.

2. Barney, J. B. (1991). Firm resources and sustained competitive advantage. Journal of Management, 17, 99-120.

3. Beer, M., Spector, B., Lawrence, P., Mills, Q., Walton, R. (1984). Managing Human Assets. New York: The Free Press.

4. Beyssere des Horts, C-H. (1988): Vers une gestion stratégique des ressources humaines, Paris, Editions d'Organisation.

5. Bourdieu, P. (1986): The forms of capital. In: Handbook of theory and research for the sociology of education. J. G. Richardson (éd.), New York, Greenwood: 241-258.

6. Breaugh, J. A., and Starke, M. (2000). Research on Employee Recruitment: So Many Studies, So Many Remaining Questions. Journal of Management, 26, 405-434.

7. Burt R. (1992). Structural Holes, The Social Structure of Competition. Harvard University Press.

8. Chambers, E. G., Foulton, M., Handfield-Jones, H., Hankin, S. M., and Michaels Ill, E. G. (1998). The War for Talent. The McKinsey Quarterly, 44-57. 
9. Cober, R.T., Brown, D.J. and Levy, P.E. (2004). Form, content and function: an evaluative methodology for corporate employment websites. Human Resource Management, 43, 201- 218.

10. Coleman, J. S. (1988). Social Capital in the creation of Human Capital. The American Journal of Sociology, 94, 95-120.

11. Defélix C. (2003). Ce que gérer les compétences veut dire, 121-128, In: Compétences et connaissances dans les organisations, A.-M. Guénette, M. Rossi et J.-C. Sardas (dir), SEES.

12. Dietrich, A. and Pigeyre, F. (2005). La gestion des ressources humaines, Paris, La Découverte, collection Repères.

13. Fondeur, Y. (2006). Internet, recrutement et recherche d'emploi: une introduction. $L a$ Revue de l'IRES, 3, 3-10.

14. Foster, L. (2005). Confronting the global brain drain.Knowledge Management Review, 8, 28.

15. Garner H., and Lutinier B. (2006). Les procédures de recrutement: canaux et modes de sélection. Premières synthèses, Dares, 48, 1-8.

16. Granovetter, M. (1973). The Strength of Weak Ties. American Journal of Sociology, $78,1360-1380$.

17. Granovetter M. (1995). Getting a Job, The University of Chicago Press.

18. Holzer, H. J. (1988). Search Method Use by Unemployed Youth. Journal of Labor Economics, 6, 1 .

19. Kalika, M. (2000). Le management est mort, vive le e-management! Revue Française de Gestion, 68-74.

20. Lee, I. (2005). The Evolution of E-Recruiting: A Content Analysis of Fortune 100 Career Web Sites. Journal of Electronic Commerce in Organizations, 3(3), 57-68.

21. Lengnick-Hall, M., Moritz, S., and Mark, L. (2003). The Impact of e-HR on the Human Resource Management Function. Journal of Labor Research, 24, 365-379.

22. Lepak, D., and Snell, S. (1998). Virtual HR: strategic human resource management in the 21st century. Human Resource Management Review, 8, 215-234.

23. Lievens, F., van Dam, K. and Anderson, N. (2002). Recent trends and challenges in personnel selection. Personnel Review, 31, 580-601.

24. Lin N., Ensel W., and Vaughn J. (1981). Social Resources and Strength of Ties: Structural Factors in Occupational Status Attainment. American Sociological Review, 46, 393-405.

25. Martin, G. and Hetrick, S. (2006). Driving corporate reputations and brands from the inside: A strategic role for HR. In: Global Reputation Institute Conference, New York, USA.

26. Martin G., Reddington M., Kneafsey M. B. and Sloman M. (2008). Web 2.0 and HRM: A Discussion Document. CIPD.

27. Maurer, S. D., and Liu, Y. (2007). Developing effective e-recruiting websites: Insights for managers from marketers. Business Horizons, 50, 305-314.

28. O'Reilly, T. (2005). What Is Web 2.0: Design Patterns and Business Models for the Next Generation of Software. O'reillynet.com.

29. Parbudyal, S., and Dale, F. (2003). The Effects of Information Technology on Recruitment. Journal of Labor Research, 24, 395-408.

30. Parry, E, and Tyson, S. (2008). Can technology transform HR processes? The case of UK recruitment. In: The Second European Academic Workshop on Electronic Human Resource Management, Carry le Rouet, 2008.

31. Peretti, J-M. (2004). Ressources Humaines, Paris, Vuibert.

32. Ployhart, R. E. (2006). Staffing in the 21st Century: New Challenges and Strategic Opportunities. Journal of Management, 32, 868.

33. Prahalad, C. K., and Hamel, G. (1990). The core competence of the corporation. Harvard Business Review, 68, 79-93

34. Putnam, R (1995). Bowling Alone: America's Declining Social Capital. Journal of Democracy, 6, 65-78.

35. Rees, A. (1966). Information Networks in Labor Markets. American Economic Review, 56, 559-566.

36. Ruël, H., Looise, J., and Bondarouk, T. (2004). E-HRM: Innovation or Irritation. An Explorative Empirical Study in Five Large Companies on Web-based HRM. Management Revue, 15, 364-380. 
